\title{
Neurofuzzy Logic Concept to Find Prakriti of a Person Using Wireless Data Acquisition System
}

\author{
Anshu Barsagade ${ }^{1}$, Prof. S. N. Joshi ${ }^{2}$, Dr. Preeti Bajaj ${ }^{3}$ \\ ${ }^{1}$ P.G. Scholar, Department of Electronics, G. H. Raisoni College of Engineering, Nagpur, India \\ ${ }^{2}$ Assistant Professor, Department of Electronics, G. H. Raisoni College of Engineering, Nagpur, India \\ ${ }^{3}$ Director, G. H. Raisoni College of Engineering, Nagpur, India
}

\begin{abstract}
Ayurveda medication, is a scheme of medication with past family tree in the Indian subcontinent. Modernized and Globalized practice originated from Ayurveda customs are a kind of balancing or else alternative medicine. This is a entire path used over diagnosis and treatment, and is a basic part of Ayurveda. Nadi parikshan is one of the method which is used for disease detection. Prakriti of person mainly depend on tridosha which includes vata, pitta and kapha. In this research work, prakriti of person is determined by using Infra Red (IR) sensor, Global System for Mobile (GSM) and Adaptive Neuro-Fuzzy Inference System (ANFIS). Infra red sensor senses the blood volume within the arterial pulse and transformed into the mathematical standards. In this scenario, Global System for Mobile is used to send patients data wirelessly. Adaptive Neuro-Fuzzy Inference System trains the data, which is saved using MySQL on web page for database. System performance and accuracy is tested using various patients database. The results show that the designed system is helpful in finding prakriti of person using wireless standard.
\end{abstract}

Keywords: Tridosha, Infrared Sensors, Global System for Mobile, Adaptive Neuro-Fuzzy Interface System

\section{Introduction}

The central traditional Ayurveda starts with famous balance sheet of spreading the medical information, and thus to human physician. Ayurveda have seven fundamental tissues, such as hemoglobin, blood, tissue, fat, bone, meat and semen. Ayurveda has traditionally separated physical substances into five elements that are water, earth, air, fire and space. These elements merge in the individual body to structure three living energies or forces named as doshas. The three doshas are Vata dosha, Pitta dosha and Kapha dosha. Normal human being has any one or an combination of two doshas among above mentioned three doshas . Every individual contains the combination two doshas which differ in rules from the other person's combination of doshas rule. For the diagnosis of pakriti of person doctor uses middle three finger to sense arterial pulse. Vata dosha, Pitta dosha and Kapha dosha are sensed exactly at the root of the wrist. The symptoms of vata dosha are body pain, arthritis, etc. The symptoms of pitta dosha are hypertension, hyper acidity, gastritis. Symptoms of kapha doshas are chest congestion and obesity. It maintains the organization and the lubrication of the body requirements. Figure 1 shows the tridosha with five basic elements.

To detect the prakriti of person data acquisition process is used. This wireless operation is performed by using GSM module. Data acquisition includes hardware, sensors, signal conditioning unit and computer software. A function of sensor is to convert any quantity into a related electrical signal.

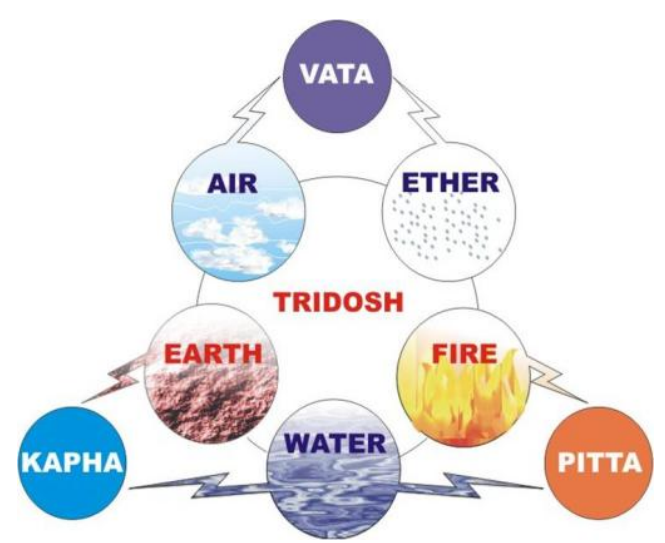

Figure 1: Tridosha with five basic elements

MySQL is free source record organization scheme. MySQL is accepted option of record for utilization of web application. Functionality that uses MySQL record include personal home page (PHP). A GSM is a wireless intermediate. GSM method is promoting as a binary method using time division multiple access (TDMA) method for transmission purpose. A GSM convert analog data into discrete data and then transmit it through a channel. In research work, the ANFIS is used to train data of various patients.

\section{Proposed Methodology}

Ayurveda is building block of an activity and judgement. For analysis of prakriti of person, arterial pulse is useful which determines the three states that are Vata, Pitta and Kapha. This genetic signal functions jointly with wireless message knowledge provides a wide range potential for directing, writing and testing of the environmental health position of 


\section{International Journal of Science and Research (IJSR) \\ ISSN (Online): 2319-7064}

Index Copernicus Value (2013): 6.14 | Impact Factor (2015): 6.391

persons. Developed model detects the diseases using Infrared sensors, wireless intermediate, and neuro-fuzzy logic concept. The figure 2 given below shows the block diagram of wireless system to determine the prakriti of person.

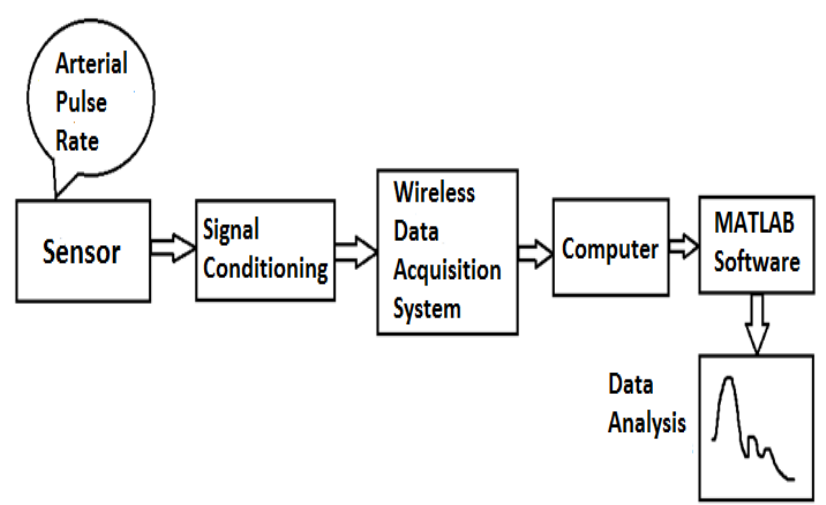

Figure 2: Block Diagram of Wireless System to determine Prakriti of Person

The main objective of research work is to find prakriti of person involving following steps:

1) Sensation of arterial pulse using infrared sensors with respect to vata, pitta and kapha.

2)IR sensor converts physical parameters into equivalent electrical signals.

3) Analog to digital converter (ADC) is used to convert analog voltage into digital value.

4)Liquid Crystal Display used for displaying average pulse rate for vata, pitta and kapha. Also waveforms of vata, pitta \& kapha are displayed.

5)GSM modem containing SIM (Subscriber Identity Module) for transmitting and reception of data using wireless intermediate.

6)PHP is used for webpage designing and MySQL for data collection on web page.

7)For superior performance of proposed system, ANFIS is used. Using data set is trained \& tested using back propogation method to detect prakriti of person. Database $\&$ history of person is saved with the help of MySQL.

The system consist two parts. That is hardware part and software part.

\section{Software Implementation}

Software part contains PHP for designing of webpage and MySQL (My Structured Query Language) for database storage. Also ANFIS (Adaptive Neuro Fuzzy Interface system) is used for training purpose and MATLAB is used for finding prakriti of person and analysis of diseases.

\subsection{Personal Home Page (PHP)}

PHP stands for Personal Home Page. It is known as serverside scripting language. With the help of PHP, webpage is designed. Also, Hyper Text Markup Language (HTML) is used while designing. Here, PHP is used as front end and HTML at back end, which has produced active web page. The use of HTML has improved designing quality of webpage. It is a popular choice for use in web application.
Figure 3 shows webpage designed with the help of PHP.5.4.3 version. The current page is showing pulse rate based disease detection with following parameters,

- Current class

- Current Mode

- Training Data

- Testing data

Also, the designing is performed in such a way that is it has select modes.

- Training mode

- Testing mode

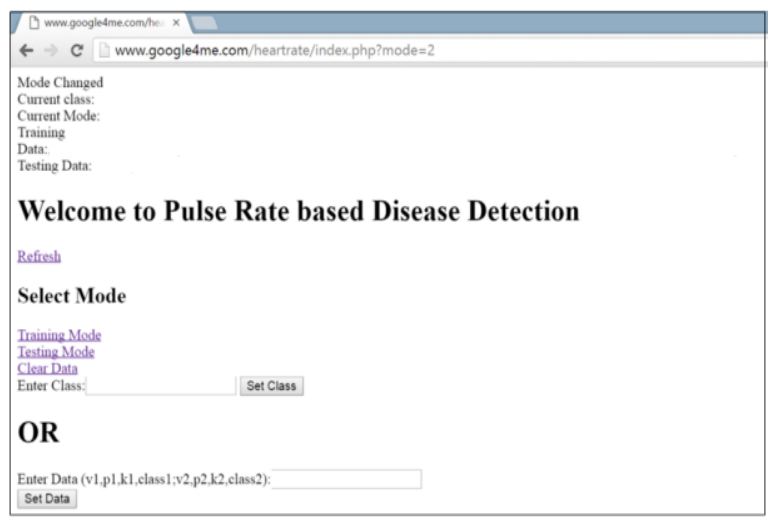

Figure 3: PHP Implementation

\subsection{MYSQL}

It stands for structured query language. MySQL provides documentation connectivity.5.5.24 version is used for implementation. MYSQL stores the readings of vata, pitta and kapha as wireless transmission is required to operate. It supports huge databases. In developed system, MySQL stores database that include 650 records. Figure 4 is representing webpage in which data as stored with MYSQL. As MYSQL is saving database, PHP is used to display that database on the webpage. The 'Data' parameter is representing database. Hardware reads data and send it to the cloud then via GSM module. For this, data need to be saved. For that purpose, MYSQL is used.

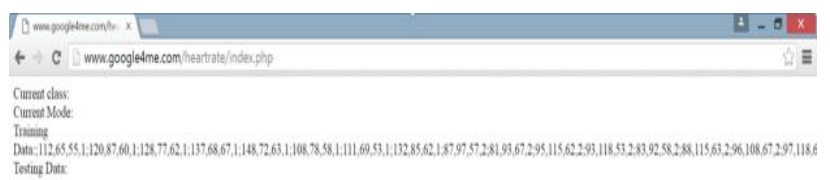

Welcome to Pulse Rate based Disease Detection

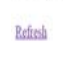

Select Mode

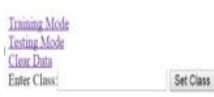

OR

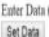

Figure 4: MYSQL Implementation

\subsection{ANFIS}

ANFIS stands for Adaptive Neurofuzzy Inference System. The ANFIS consists of two mechanism, fuzzy inference

\section{Volume 5 Issue 6, June 2016} www.ijsr.net 


\section{International Journal of Science and Research (IJSR) \\ ISSN (Online): 2319-7064 \\ Index Copernicus Value (2013): 6.14 | Impact Factor (2015): 6.391}

systems as well as neural networks with a known input and output information set. The adaptive network based fuzzy inference system is an information focused method indicating a neural network for the answer key to estimate accurate system. Information focused procedures for the production of ANFIS networks are depend on clustering a instruction set of mathematical samples of the vata, pitta and kapha. ANFIS networks applied to organization tasks related to training values of vata, pitta and kapha. The input parameters for ANFIS is amplitude of pulse and output is disease type. ANFIS training can use to decrease the errors in the training.

Implementation steps of ANFIS

- To implement ANFIS in online mode, anfisedit command is used to generate anfis editor window.

- To load readings of vata, pitta and kapha from webpage to the MATLAB window, workspace is selected thus data get loaded

- After that, fuzzy interface system is generated using sub clustering which classifies vata, pitta and kapha.

- For training of fuzzy interface system, back propagation algorithm is used as producing output in optimum stages.

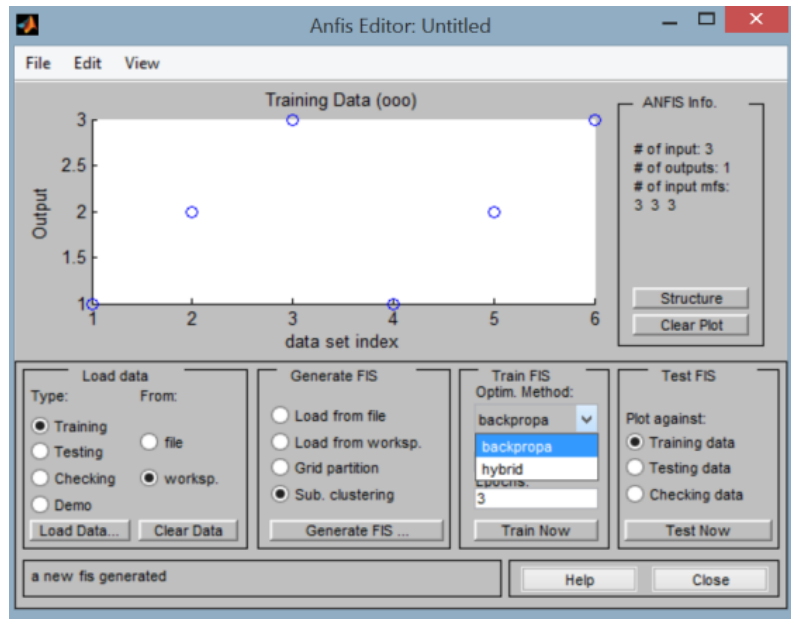

Figure 5: Sub-clustering

- 1000 epochs are selected to perform training. Followed by this, training windows displays.

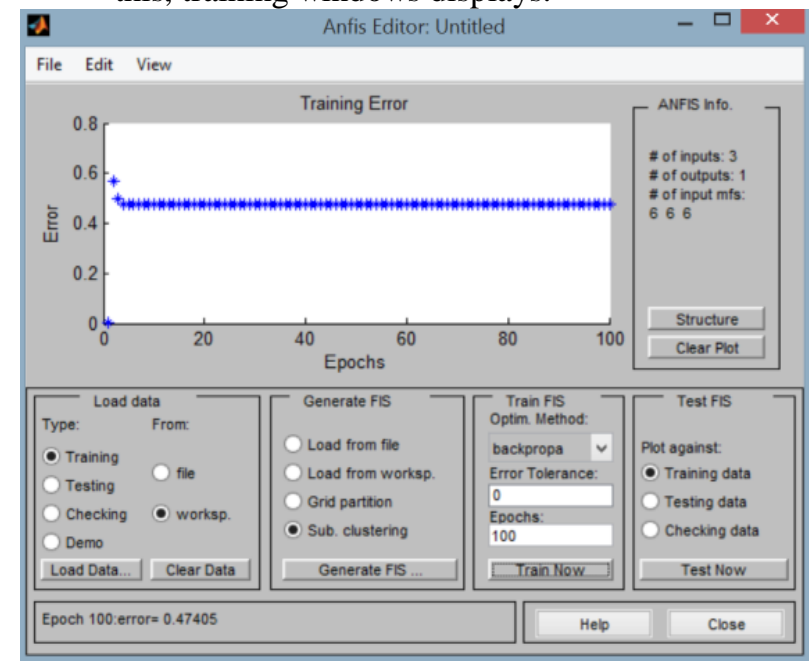

Figure 6: Training Process
- After this step, data file need to export in order to generate fis file which is useful while testing.

- Thus, output screen with ANFIS displays.

\section{Hardware Description}

Figure 7 shows the hardware part of research work that contains infrared sensors, operational amplifier, microcontroller, liquid crystal display and GSM modem.

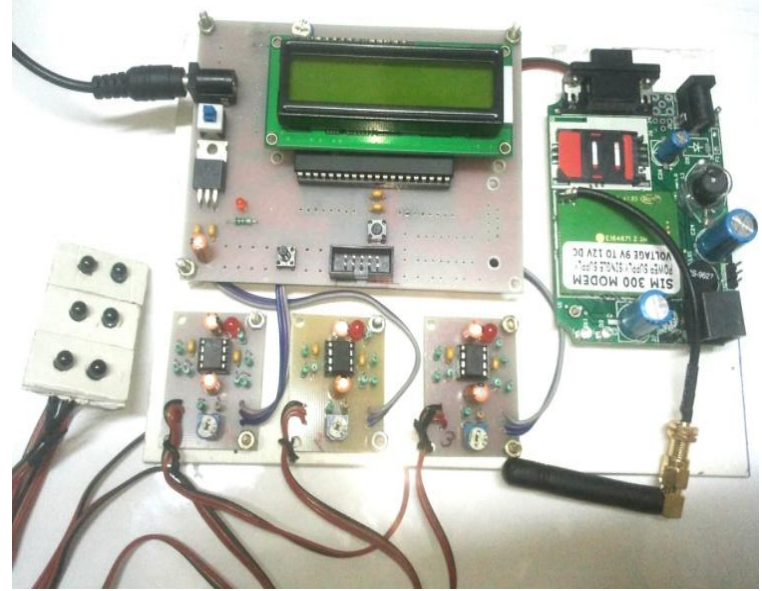

Figure 7: Hardware For Data Acquisition System to determine Prakriti of Person.

The infra red sensor consists of an infrared LED as well as photo diode. The first diode that is IR LED sends an infrared radiance into the arterial pulse and photo diode senses reflected light from the blood inside the arterial pulse. The strength of light measures the blood quantity within the arterial pulse. Using high gain amplifier, little changes in the amplitude of the reflected light can be transformed into a pulse. It has operation range between $(10-80) \mathrm{cm}$. The operational amplifier used in the system is LM358 (Linear Monolithic 358). This piece of equipment consists of two self-sufficient, high increase frequency-compensated functioning amplifier device to work from a single over a broad series of voltages. This device eliminates need for dual supplies it is made up of two operational amplifiers. It is 8 pin integrated circuit. It has broad range of power delivery. The microcontroller will manage each unit in the transmitter division. The IR sensor senses the blood volume inside the arterial pulse as analog signal. With the use of analog to digital converter these analog signals are transformed to digital and it is passed to the microcontroller. Microcontroller executes the digital signal and then sends the digital signal through the wireless transmitter unit as an analog signal. ATMEGA 16 microcontroller is used for the operation to be performed. Here, microcontroller is used as interfacing device between 3 IR sensors and LCD display. Liquid crystal display is showing readings of vata, pitta and kapha. The amplitude range of blood inside the arterial pulse is shown on LCD display. It is available in 16 pin package. Here, data register stores a data which displays on the LCD. In research work, SIM300 is used as a Global system for mobile. It may transfer a data from transmitter to receiver over a wireless medium without encrypting data. The benefit of GSM is finest safety execution, structural design and progress of the wireless system. SIM 300 requires power 


\section{International Journal of Science and Research (IJSR) \\ ISSN (Online): 2319-7064 \\ Index Copernicus Value (2013): 6.14 | Impact Factor (2015): 6.391}

supply of $3.4 \mathrm{~V}-4.5 \mathrm{~V}$. The downlink data GPRS -880-915 $\mathrm{MHz}$ and uplink data is $925-960 \mathrm{MHz}$. SIM is used as Subscriber Identity Module used as memory device in it. For sending and receiving data, AT command is used.

\section{Result and Discussion}

Research work is developed for prakriti detection and diseases detection. Figure 8 shows workflow adopted for research work.

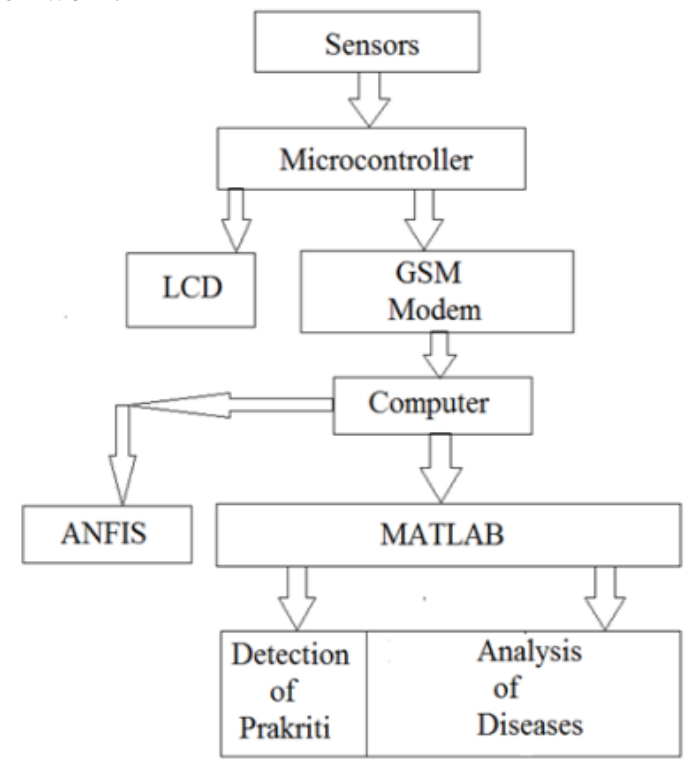

Figure 8: Work Flow of Research Work

The IR sensors are placed on wrist with respect to accurate position of vata, pitta and kapha. Left hand of female and right hand of male is used for pulse diagnosis.

Position- Vata: Index finger

Pitta: Middle finger

Kapha: Ring Finger

Overall Time- $60 \mathrm{Sec}$.

Number of samples- 150

Normal Amplitude range - Vata: 80-100

Pitta: 60-90

Kapha: 50-70

The pulse [18] is measured for 1 minute for diagnosis of vata, pitta and kapha readings. The data is collected based on amplitude range of vata, pitta and kapha. The amplitude and shape of the arterial pulse is considered for determining pulse patterns and detection of diseases.

\subsection{Result For Normal Person}

According to the ayurveda medicine system[18], when vata, pitta and kapha are in normal amplitude range as mentioned above then the person is in normal state.

After taking the number of readings, it will be displayed on the web page on receiver's side for normal person as shown in figure 9(a) given below. ANFIS has been carried out for 90 normal persons.

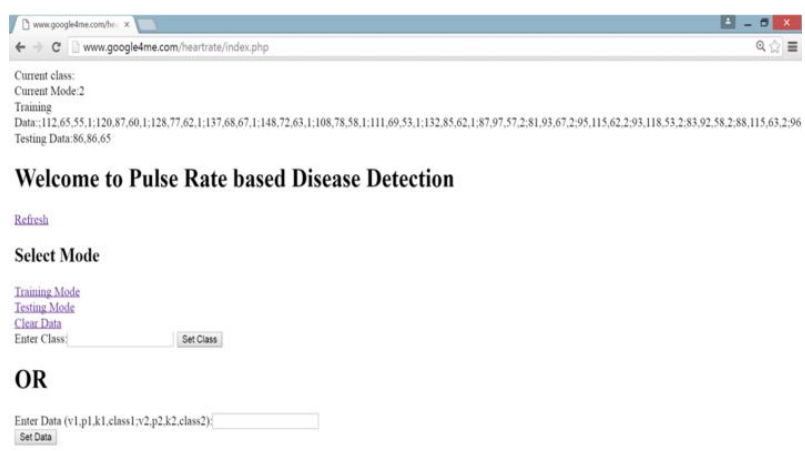

Figure 9(a): Web Page Display for Normal Person

While the data is being transmitted on the receiver's side, MATLAB command window displays doshas and pulse pattern with respect to the vata, pitta and kapha. Below figure 9(b) shows display menu for normal person.

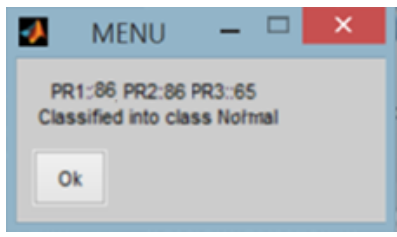

Figure 9(b): Display which showing normal doshas with respect to vata, pitta and kapha for normal person

Amplitude of normal person is within the stated normal amplitude range. Figure 9(c) shows pulse pattern of vata, pitta and kapha for normal person.

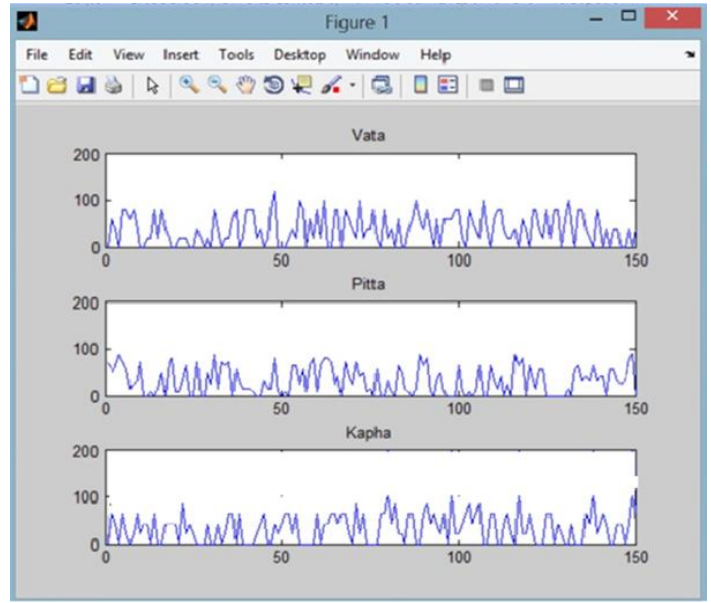

Figure 9(c): Pulse Pattern of vata, pitta and kapha for normal person

\begin{tabular}{|c|c|c|c|c|c|c|c|c|}
\hline Sr: No. & Gender & Age & Weight & $\begin{array}{l}\text { Blood } \\
\text { Group }\end{array}$ & $\begin{array}{l}\text { Puls } \\
\text { V }\end{array}$ & $\begin{array}{c}\mathrm{Ra} \\
\mathrm{P}\end{array}$ & K & $\begin{array}{l}\text { Body } \\
\text { Constitution }\end{array}$ \\
\hline 1 & Person1(M) & 23 & 53 & $\mathrm{~B}^{+}$ & 90 & 75 & 61 & Normal \\
\hline 2 & Person2(M) & 28 & 41 & $\mathrm{AB}$ & 98 & 91 & 74 & Pitta Kapha \\
\hline 3 & Person3(F) & 24 & 48 & $0+$ & 99 & 75 & 65 & Normal \\
\hline 4 & Person4(M) & 21 & 55 & $\mathrm{~A}^{+}$ & 101 & 74 & 75 & Vata Kapha \\
\hline 5 & Person5 (F) & 25 & 57 & $0+$ & 84 & 75 & 61 & Normal \\
\hline
\end{tabular}

Figure 9(d): Database For Normal Person 


\section{International Journal of Science and Research (IJSR) \\ ISSN (Online): 2319-7064 \\ Index Copernicus Value (2013): 6.14 | Impact Factor (2015): 6.391}

\subsection{Result of Person Having Liver Disease}

According to paper [17] and ayurveda medicine system, liver disease causes due to the imbalance of pitta dosha. The person having liver disease is having high amplitude for the pitta as compare to normal range. [17]Liver is known as place of Pitta. Pitta is accredited to liver. Liver is considered as, the origin of Raktavahasrotas. So, liver is very much important in all diseases concerned with Raktavahaand PittavahaSrotas. ANFIS has been carried out for 70 number of persons for liver disease. The reading will be display on the web page on receiver's side for liver disease person as shown in figure $10(\mathrm{a})$.

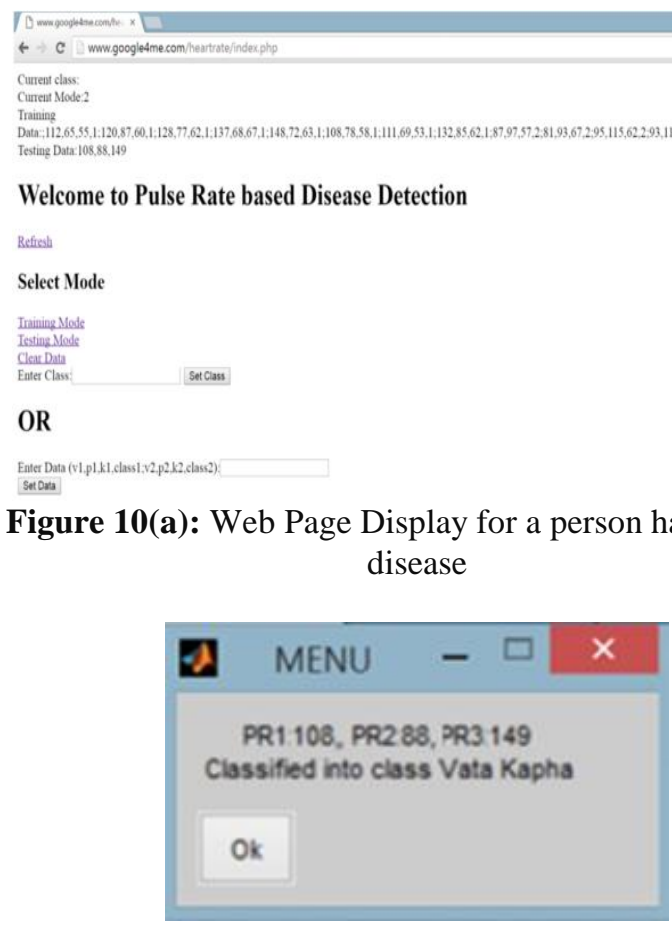

Figure 10(b): Display having higher pitta dosha for liver problem

Figure 10(b) represents values of amplitude for person having liver disorder. Also, according to that the categorization of the class is mentioned. Figure 10(c) shows pulse pattern is obtained for person having pitta dosha that is liver disease. In addition, it has the broadening effect

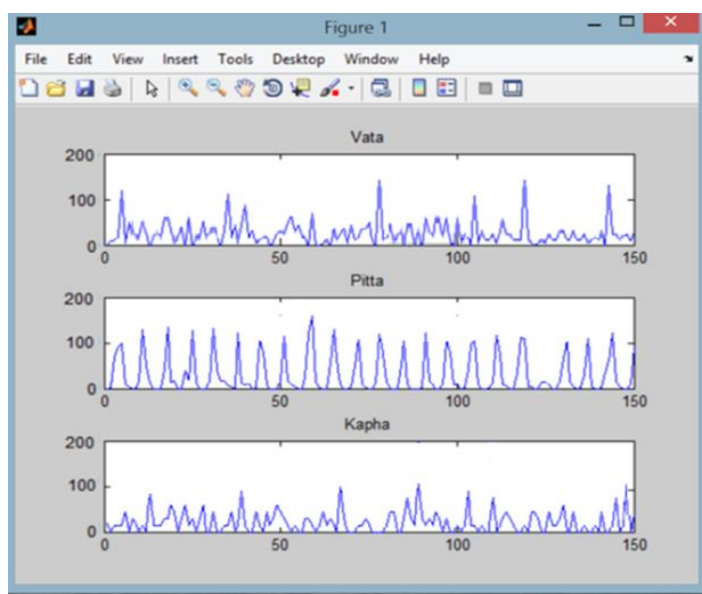

Figure 10(c): Pulse pattern of Vata, Pitta and Kapha for Person Having Liver Disease
Below figure 10(d) shows readings of persons having liver disease.

\begin{tabular}{|c|c|c|c|c|c|c|c|}
\hline Sr. No. & Gender & Age & Weight & $\begin{array}{l}\text { Blood } \\
\text { Group }\end{array}$ & $\begin{array}{l}\text { Pulse Rat } \\
\text { V P }\end{array}$ & $\mathrm{K}$ & $\begin{array}{l}\text { Body } \\
\text { Constitution }\end{array}$ \\
\hline 1 & Personl(F) & 25 & 45 & $0+$ & 106133 & 69 & Vata Pitta \\
\hline 2 & Person2(M) & 24 & 54 & $\mathrm{~B}^{+}$ & $\begin{array}{ll}88 & 137\end{array}$ & 86 & Pitta Kapha \\
\hline 3 & Person3 (F) & 23 & 48 & $0+$ & 113149 & 61 & Vata Pitta \\
\hline 4 & Person4(F) & 22 & 51 & $\mathrm{AB}$ & $90 \quad 144$ & 61 & Pitta \\
\hline 5 & Person5 (M) & 21 & 56 & $\mathrm{~A}^{+}$ & 109133 & 77 & Vata Pitta \\
\hline
\end{tabular}

Figure 10(d): Database for Person Having Liver Disease

\subsection{Result of Person Having Diabetes Problem}

According to paper[14] and Ayurveda Medicine System, diabetes causes due to the imbalance of kapha dosha. The pulse rate of person having diabetes disease is high for the kapha dosha as compare to normal range. ANFIS has been carried out for 85 number of persons for diabetes. [14]Ayurveda identifies mainly 20 types of diabetes. 4 due to Vata imbalance, 6 due to Pitta imbalance and 10 due to Kapha imbalance. The reading will be display on the web page on receiver's side for diabetes person as shown below.
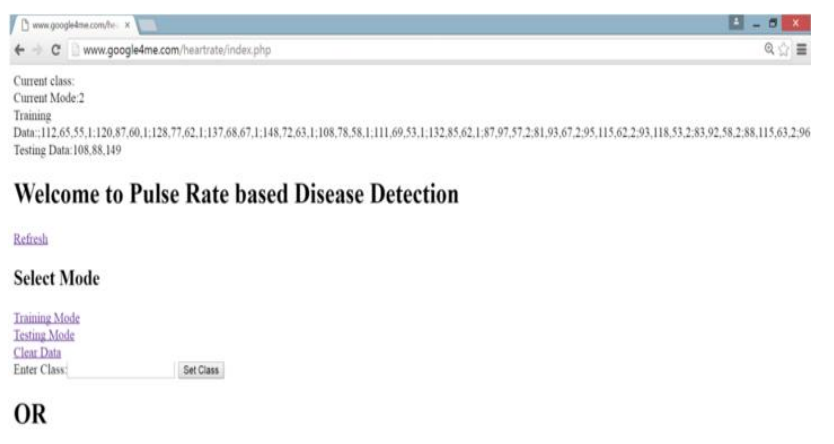

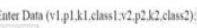

Figure 11(a): Web Page Display for a person having Diabetes

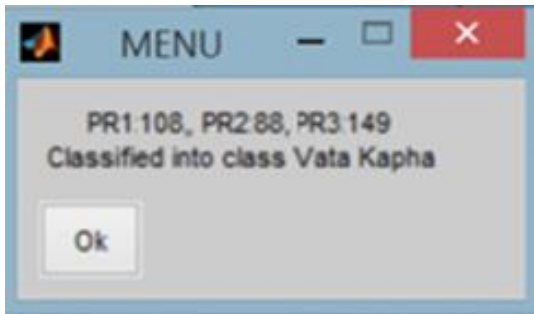

Figure 11(b): Display which is showing higher kapha dosha for diabetes

Figure 11(b) shows amplitude of pulse in numeric format. Also, accordingly their categorization of class. Pulse pattern is obtained for person having kapha dosha means diabetes. The amplitude range of pulse pattern for kapha dosha is greater than that of normal amplitude range of doshas. In addition, it has the broadening effect. Figure 11(c) shows pulse pattern of vata, pitta and kapha for person having Diabetes. This pattern is displayed according to the ranges mentioned[18]. Figure 11(d) represents the database of persons having diabetes with their combination of imbalances in vata kapha, kapha pitta etc.

Volume 5 Issue 6, June 2016 www.ijsr.net 


\section{International Journal of Science and Research (IJSR) ISSN (Online): 2319-7064}

Index Copernicus Value (2013): 6.14 | Impact Factor (2015): 6.391

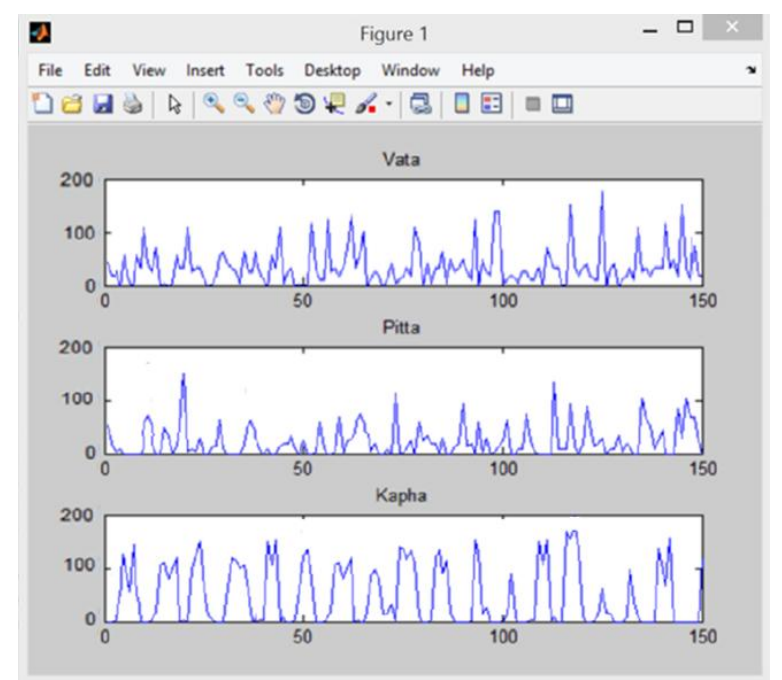

Figure 11(c): Pulse pattern of vata, pitta and kapha for person having Diabetes

\begin{tabular}{|c|c|c|c|c|c|c|c|c|}
\hline Si: No. & Gender & Age & Weight & $\begin{array}{l}\text { Blood } \\
\text { Group }\end{array}$ & $\begin{array}{l}\text { Puls } \\
\text { V }\end{array}$ & $\begin{array}{l}\text { e Rate } \\
\text { P }\end{array}$ & $\mathrm{e}$ & $\begin{array}{l}\text { Body } \\
\text { Constitution }\end{array}$ \\
\hline 1 & Personl(F) & 32 & 48 & $\mathrm{~B}^{+}$ & 102 & 861 & 132 & Vata Kapha \\
\hline 2 & Person2(F) & 38 & 57 & $\mathrm{~B}^{+}$ & 113 & 74 & 148 & Vata Kapha \\
\hline 3 & Person3(F) & 35 & 43 & $A B$ & 90 & 75 & 137 & Kapha \\
\hline 4 & Person4(M) & 66 & 53 & $\mathrm{~A}^{+}$ & 97 & 69 & 147 & Kapha \\
\hline 5 & Person5 (M) & 31 & 58 & $A B$ & 87 & 98 & 130 & Kapha Pitta \\
\hline
\end{tabular}

Figure 11(d): Database for Person Having diabetes

\section{Conclusion}

Pulse Diagnosis is one of the best methods of determining the health condition of the person. Pressure applied on three pulse spot that is vata, pitta and kapha are the focal elements in the prediction of health condition in ayurveda system. Arterial pulse signal for normal condition shows normal pulse pattern, while in abnormal health condition the pulse pattern shows high amplitude range with broadening effect. Experimentally, it is observed that liver disease exists in pitta dosha and diabetes disease lies in kapha dosha. The classification of dosha and pulse pattern shows the significant result which are observed in outcome.

In this research work, we uses GSM technique as a wireless medium, which is used for global communication with additional features of large range access and ANFIS for training purpose. ANFIS provides a flexible way to different classes and diagnose the disease according to database. The ANFIS training is very effective in enhancing the classification accuracy of pulse signal.

\section{Future Work}

Ayurveda medicine is a system of cure with ancient families in India believes in knowledge from the three points on the wrist for analysis. In transmit logic, data acquisition is the method of assembly of data in an automated manner and presenting information in a important technique in medical application. Using wireless data acquisition system in actual moment is challengeable work, as it depends on more careful way to sense the arterial pulse signal from wrist. As far as the noise interference concerned, new sensors can be designed for taking concern changing location of the sensors. Maximum number of database for individuals will be necessary for higher precise results. As the variation in pulse sample of three points that are vata, pitta and kapha found clearly, working at the deep, we can predict other diseases related to tridosha using this method.

\section{References}

[1] M-Elena, J.M. Quero, S.L. Toral, C.L. Tarrida, J.A. Segovia, L.G Franquelo, "Intelligent Cardiology Monitoring System Using GPS/ GPRS Networks", 2002IEEE

[2] Robert X. Gao and Philipp Hunerberg, "Design of a CDMA-Based Wireless Data Transmitter for Embedded Sensing", IEEE Transaction on Instrumentation and Measurement, Vil. 51, No.6, December 2002

[3] Anna Cysewska-Sobusiak, Arkadiusz Hulewicz, Michal Boltrukiewicz and Dariusz Prokop, "Utilization of Human-Computer Interaction in Wireless Transmission of Arterial Pulse Waveforms" IEEE International Conference on virtual Environments, Human-Computer Interfaces and Measurement systems, Giardini Naxos, Italy, 18-20 July 2005

[4] Javier Espina, Thomas Falck, Jens Muehlsteff, and Xavier Aubert, "Wireless Body Sensor Network for Continuous Cuff-less Blood Pressure Monitoring", Proceedings of the third IEEE-EMBS. International Summer School and Symposium on Medical Devices and Biusensors MIT, Boston,USA, Sept 4-6,2006

[5] Kai Wu and Xiaoming Wu, "A Wireless Mobil Monitoring System for Home healthcare and Community Medical Services" 2007 IEEE

[6] Stephen R. Alty, Natalia Angarita-Jaimes, Sandrine C. Millasseau and Philip J. Chowienczyk, "Predicting Arterial Stiffness From the Digital Volume Pulse Waveform", IEEE Transaction on Biomedical Engineering, Vol. 54, No. 12, December 2007

[7] Joni Jantunen, Antti Lappetelainen, Jarmo Arponen, Aarno Parssinen, "A New Symmetric Transceiver Architecture For Pulse Short-Range Communication ”, IEEE Communications Society Subject Matter Expert For Publication in the IEEE "GLOBECOM" 2008

[8] Yu-Chi Wu And Pie- Fen Chen, "Multi-Channel DataAcquisition and Cntriller for mobile Health Monitoring System with HSDPA and GPS", 2009 IEEE

[9] Ovidiu Apostu, Bogdan Hagiu, Sever Pasca, "Wireless ECG Monitoring and Alarm System Using ZigBee", The $7^{\text {th }}$ International Symposium on ADVANCED Topics in Electrical Engineering, Bucharest, May 12-14, 2011 ATEE

[10]Chih-Chung Huang, Po-Yang Lee, Pay-Yu Chen and Ting-Yu Liu, "Design and Implementation of a Smartphone Based Portable Ultrasound Pulsed-Wave Doppler device for Blood Flow Measurement", IEEE Transaction On Ultrasonic, Ferroelectrics, and Frequency Control. Vol. 59. No. 1, January 2012

[11]Liang-Hung Wang, Tsung-Yen Chen, Shuess-Yuh Lee, Tai-Hsuan Yang, Shin-Yan Huang, Jen-Hao Wu and

\section{Volume 5 Issue 6, June 2016 www.ijsr.net}


Kuang- Hao Lin, "A Wireless Electrocardiogram Detection for Person Health Monitoring", National Chin Yi University of Technology, Taichung, Taiwan, 2013 IEEE

[12] Hongqiao Gao, Xiaohui Duan, Xiaoqiang Guo, Anpeng Huang and Bingli Jiao, "Design and Tests of a Smartphones-based Multi-lead ECG Monitoring System", 2013 IEEE

[13] Milan stork and David Tolar, "Wireless Electronic Systems For Physiological Parameters Measuring" Research has been supported by the European Regional Development Fund and by Internal project SGS-2013026

[14] Angella McGinnis,"The Roll of Ayurveda in the Treatment of Diabetes/ Madhumeha", SGS-2013-026 2014

[15]Luca Fanicci, Sergio Saponara, Tony Bacchillone, Massimiliano Donati, Pierluigi Barba, Isabel SanchezTazo and Cristina Carmona, "Sensing Devices and Sensor Signal Processing for Remote Monitoring of Vital Signs in CHF Patients", IEEE Transactions on Instrumentation and Measurement, vol. 62, No. 3, March 2013

[16] Mohammad Derawi, Iurill Voitenko, Pal Erik Endrerud, "Real-time Wireless ECG Biometrics with Mobile Devices", International Conference on Medical Biometrics,2014 IEEE

[17]Neha Dubey, Rashmi Pandey, A.C. Kar "DIFFERENTIAL DIAGNOSIS IN YAKRITA VIKARA (LIVER DISEASES) DESCRIBED IN AYURVEDA", www.iamj.in IAMJ: Volume 3; Issue 7; July- 2015

[18] http://ayurvedaforyou.com/clinical_ayurveda/pulse_diagnosis.html 